DOI: https://doi.org/10.31992/0869-3617-2020-29-2-151-158

\title{
The Profile Improvement of Vocational School Teachers' Competencies
}

Bruri M. Triyono - Dr. (PhD) of Education, Prof., Head of Department VET, Faculty of Engineering and Postgraduate Program in Technology and Vocational Education, Director Graduate School, Orcid ID: 0000-0001-5720-9604, e-mail: bruritriyono@uny.ac.id,

Indonesia Yogyakarta State University (Universitas Negeri Yogyakarta), Yogyakarta, Indonesia

Adress: Jl. Colombo No.1, Karang Malang, Caturtunggal, Kec. Depok, Kabupaten Sleman, Daerah Istimewa Yogyakarta 55281, Indonesia

Najoua Mobib - Dr. (PhD) of Education, Assoc. Prof., UNISTRA Faculty of Educational Sciences, e-mail: najoua.mohib@unistra.fr

University of Strasbourg, Strasbourg, France

Address: 4 rue Blaise Pascal, CS 90032, F-67081, 67070 Strasbourg Cedex, Strasbourg, Alsace, France

Gulzhaina K. Kassymova - Doctoral (PhD) candidate, Orcid ID: 0000-0001-7004-3864, e-mail: zhaina.kassym@gmail.com

Abai Kazakh National Pedagogical University, Almaty, Kazakhstan

Address: 13, Dostyk avenue, 050010, Almaty, Kazakhstan

Graduate School Universitas Negeri Yogyakarta

Address: Jl. Colombo No.1, Karang Malang, Caturtunggal, Kec. Depok, Kabupaten Sleman, Daerah Istimewa Yogyakarta 55281, Indonesia

Galeb N. I. P. Pratama - Lecturer in Department of Civil Engineering Education and Planning, Faculty of Engineering, e-mail: galeh@uny.ac.id

Graduate School Universitas Negeri Yogyakarta, Yogyakarta, Indonesia

Address: Jl. Colombo No. 1, Karang Malang, Caturtunggal, Kec. Depok, Kabupaten Sleman, Daerah Istimewa Yogyakarta 55281, Indonesia

Dina Adinda - Doctoral (PhD) candidate, Assoc. Prof., Orcid ID: 0000-0002-5879-1349, e-mail: d.adinda@unistra.fr

University of Strasbourg, France

Address: 4 rue Blaise Pascal, CS 90032, F-67081, 67070 Strasbourg Cedex, Strasbourg, Alsace, France

Mariyam R. Arpentieva - Dr. (grand PhD) Sci. (Psychology), Assoc. Prof., Prof. of the Department of Developmental Psychology and Education, e-mail: mariam_rav@mail.ru

K.E. Tsiolkovskiy Kaluga State University, Kaluga, Russia

Address: 26, Razin str., Kaluga, 248023, Russia

Abstract. This study is aimed to reveal the improvement in the competency of productive teachers of both state and private vocational high schools in Sleman Regency after participating in a self-development program in terms of psychological maturity and socio-cultural aspects. This study was carried out in two state vocational high schools SMKN 1 Sedayu and SMKN 1 Seyegan, and one private vocational high school SMK Muhammadiyah Pakem. It was a qualitative study in nature using interview and documentation as the means of collecting the data. Fifteen produc- 
tive teachers of the three vocational high schools with expertise in Building Engineering Drawing (BED) were purposively selected to be the research subjects. The obtained data in the form of interview tapescripts, photos, and documents were triangulated to ensure data validity. The data were then analyzed systematically through three main stages including open coding, axial coding, and selective coding. The results show that through self-development, the BED productive teachers in state vocational high schools can improve their pedagogical and professional competencies. In addition, this program also develops their knowledge and skills in the areas of curriculum, expertise, technology, as well as teaching strategies and methods. Even so, in the case of BED productive teachers in private vocational high schools, this self-development program does not significantly improve their competencies.

Keywords: pedagogical competence, professional competence, self-development, vocational high school

Cite as: Triyono, B.M., Mohib, N., Kassymova, G.K., Pratama, G.N.I.P., Adinda D., Arpentieva, M.R. (2020). The Profile Improvement of Vocational School Teachers' Competencies. Vysshee obrazovaniev Rossii = Higher Education in Russia. Vol. 29, no. 2, pp. 151-158.

DOI: https://doi.org/10.31992/0869-3617-2020-29-2-151-158

\section{Introduction}

To create quality education, it is imperative to create quality teachers as well. Law Number 14 Year 2005 on Teachers and Lecturers mentions that quality teachers are those who can meet the demands of life changes by making continuous quality improvements in accordance with the development of science and technology. Low quality teachers will make national human resources difficult to develop. O. Marijan reveals that most Indonesian teachers are of low quality and this is because national examination scores tend to be used as a standard for teacher assessment and there is no cadre regeneration of quality teachers [1]. Teachers are not the main reason behind low quality education, but the improvement of teacher quality is an absolute requirement that must be fulfilled to realize quality education [2]. In addition, the uneven distribution of teachers has made it difficult for teachers in remote areas to develop their self-quality. D. Maulipaksi says that the number of teachers in Indonesia is quite large [3]. The ratio of teachers and students in Indonesia (1:17) is generally better than that in Korea (1:32) and Japan (1:26). However, this will not have a positive impact if the quality of the existing teachers is not good.

The certification program in an effort to improve teacher competency and quality has not yet fulfilled the expected goals [4]. Susanti states that all this time the government has made a number of efforts to improve teacher competencies, among others through technical guidance, workshops, seminars, training on classroom action research, mentoring, and revitalization [5]. R. Hartono adds that the government has tried to improve the quality of teachers by increasing the capacity and professionalism of teachers through continuous education and training [6].

Some government policies regarding teacher competency improvement, specifically Law Number 14 Year 2005 regarding Teachers and Lecturers, state that in carrying out professionalism tasks, teachers are obliged to continuously improve and develop their academic qualifications and competencies in line with the development of science, technology, and the arts. Furthermore, it was also stated that teacher empowerment was carried out through selfdevelopment programs that were carried out in a democratic, fair, non-discriminatory, and sustainable manner by upholding human rights, religious values, cultural values, national plurality, and professional codes of ethics. Various teacher capacity building programs through the preparation of teacher certification have been implemented by the government as mentioned earlier, but one thing that is still rarely 
implemented is self-awareness to develop their own capacity as professional teachers.

Self-development without careful planning will not be able to improve the quality of the teachers. Self-development of teachers can be done through educational and training activities or through teacher collective activities. S. Creten and $\mathrm{S}$. Huyghe emphasize that through self-development, participants are able to create their own training programs, have freedom in managing their time, and are able to make changes at the curriculum level through collaboration with colleagues to optimize the learning outcomes [7]. Furthermore, Y. Gulec-Aslan argues that teachers' knowledge and skills will increase when the training offered is truly well-designed [8].

Vocational high schools (VHS) play a role as a means for developing student skills in which the level of success is largely determined by the role of productive teachers. Al W. Hijriyah reports that the increasing public interest in continuing education in vocational high schools does not match the available number of productive teachers [9]. For example, data from the Central Java Education, Youth, and Sports Office show that vocational high schools in Boyolali are short of 99 productive teachers. On the other hand, Boyolali urgently needs vocational schools with study programs that can support the industry development in Boyolali, given the increasing number of enthusiasts such as in the field of Building Engineering. Building Engineering is a study program that is increasingly in demand by the public as growth and equity in the infrastructure sector continue to increase.

\section{Method}

It was a qualitative study with as many as fifteen state and private vocational school teachers in Building Engineering Drawing study program as the research subjects. This study was carried out in two state vocational high schools SMKN 1 Sedayu and SMKN 1 Seyegan, and one private vocational high school SMK Muhammadiyah Pakem. The data were collected through interview and documentation. The ob- tained data were analyzed through three main stages including open coding, axial coding, and selective coding. The data were then presented descriptively.

\section{Results and Discussion}

In general, the importance of training successful (productive and effective) teachers has been repeatedly noted by us $[1 ; 10-15]$ and other researchers $[2 ; 4 ; 6 ; 16-18]$.

Teachers who are active in developing themselves can be more confident in delivering the materials, both knowledge and skills, to the students. Through a self-development program, they change themselves to a better teacher, especially in their expertise field. Along with their increasing knowledge, they can be more determined in teaching. Moreover, they would become more confident for the students can get actual information that is not based on textbook only.

Teachers who often participate in self-development programs will become more active in carrying out activities, either within the school, industry, or community. They will always make movements in the effort to develop student competencies. Various movements that they do include: trying to get competency certificates in the hope that they can establish their own competency test center in the scope of the vocational school and have the right to issue competency certificates to students after they pass certain competencies.

The picture above describes that self-development in productive teachers in vocational schools has provided significant changes to the aspect of psychological maturity. In terms of psychosocial aspect, teachers have a better work orientation and time management, have better self-disclosure, and show high enthusiasm as their determination increases. They become more confident and feel more motivated. Furthermore, changes also occur in their intraand interpersonal characters, for example, they become more disciplined, more adaptive, more active, and more determined to carry out their roles and duties as educators. 


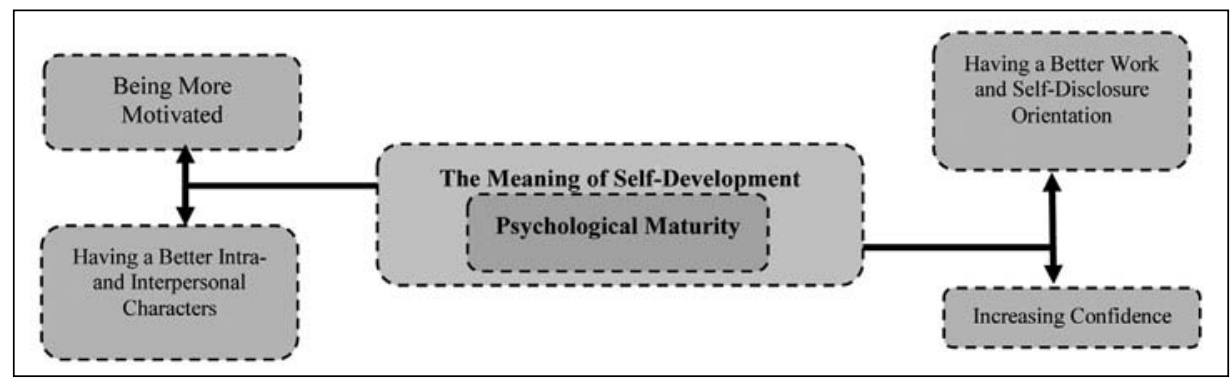

Fig. 1. The Meaning of Self-Development to Productive Teachers of Vocational High Schools on Psychological Aspects

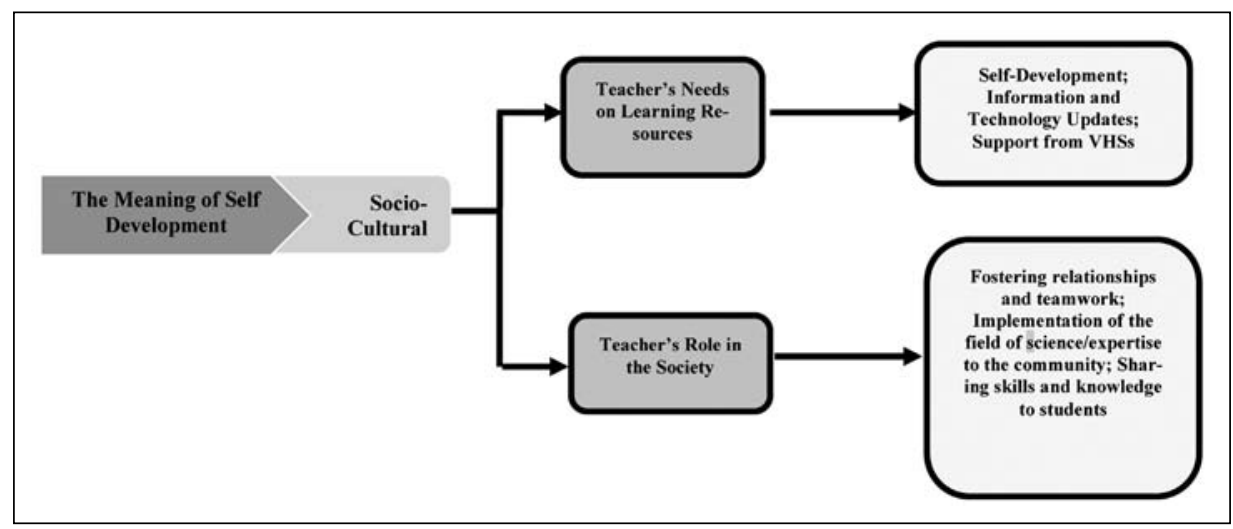

Fig. 2. The Meaning of Self Development of Productive Vocational Teachers on Socio-Cultural Aspects

From the findings, it is obvious that the number of teachers participating in self-development efforts improve their motivation and selfconfidence. The analysis was carried out based on the categorization of the interview data related to motivation and self-confidence by using four criteria, namely: (a) criterion I - improvement of teacher motivation and self-confidence; (b) criteria II - improvement of teacher's confidence, but not motivation; (c) criteria III - no improvement in terms of teacher's motivation and self-confidence; and (d) criteria IV - improvement of the teacher's motivation, but not their confidence. Based on the results, the percentage of criteria I was $73.3 \%$; criteria II and III amounted to $13.4 \%$; and criteria IV by $0 \%$.

The meaning of self-development in the socio-cultural aspects can be seen as a reciprocal relationship between teachers and their social environment (Fig. 1). Teachers need the roles of the social environment in meeting the needs of learning resources to be able to improve their competencies. In addition, teachers also play an important role in carrying out their duties as educators in their social environment. Through self-development efforts among teachers, they can be co-motivators for each other as no teacher can truly master all the sciences in one scientific field.

Based on Figure 2, self-development of productive teachers in state vocational schools has provided various benefits meaningful for the socio-cultural aspects. The benefits may include: (1) helping the teachers to meet the needs of learning resources due to the role of the social environment, including: self-development, technology and information updates, and support from the VHSs; (2) improvement of the roles of teachers in the society, among others: teachers can foster teamwork with the external parties 
(relationship with colleagues, self-development implementing agencies, and industrial parties), teachers can convey their knowledge and skills to students, and teachers can apply their knowledge for the public needs.

Additionally, the psychological maturity aspect tends to change the psychological development of the teachers towards a certain level of maturity, giving changes to them in the forms of rewards, namely feelings of pleasure, satisfaction, and appreciation, while in the sociocultural aspect, the teachers will disseminate the benefits to students, the school environment, colleagues, and the wider community. The psychological maturity aspect provides a big change for them, in which the changes that are felt will bring benefits to the socio-cultural aspects of the teacher in the school environment and outside the school. Besides, the meaning of self-development for teachers in terms of psychological and socio-cultural maturity aspects in the improvement of pedagogical and professional competencies can create a pattern based on relationships between the existing categories. In this case, one core category was identified which became the central point of the research, namely "meaningful self-development" with quality, intensive and measurable indicators.

Some of the improvements in pedagogic competences that can be felt by teachers after participating in various self-development programs include: (1) obtaining a lot of knowledge about the understanding and development of teaching instruments; (2) becoming more organized in managing their teaching administrative documents; (3) being able to apply Problem Based Learning and Project Based Learning methods; (4) being capable of applying appropriate teaching concepts in classes and becoming more skilled in delivering the learning materials, so that the teaching and learning process becomes more effective; (5) being able to further develop the scope of knowledge taught to students as outlined in a standard of assessment; (6) getting a lot of input and description about the strategies and teaching methods for effective learning; (7) being able to make the learning objectives clearer, so does the learning materials and sequences, so that teachers become more ready and confident in teaching. Furthermore, they (8) can develop their understanding of new and sophisticated learning media through modules obtained from self-development activities. In addition to pedagogical competencies, teachers also may experience improvements in terms of professional competences, including: (1) updating their knowledge in the vocational field; (2) understanding the contents of the materials and the teaching sequences; (3) standardizing the sequences of competencies that will be taught with teachers of other schools; (4) being more skilled in providing demonstrations on practical subjects; (5) finding out the latest software in the building engineering field in accordance with technological development; and (6) exploring teaching materials through the Internet.

\section{Conclusions}

It is clearly stated from the results of this study that self-development for productive teachers of Building Engineering Drawing Study Program in Vocational High Schools (VHSs) can cause some improvements on their pedagogical and professional competencies. Some of the improvements in pedagogic competences that can be felt by teachers after participating in various self-development programs include: (1) obtaining a lot of knowledge about the understanding and development of teaching instruments; (2) becoming more organized in managing their teaching administrative documents; (3) being able to apply Problem Based Learning and Project Based Learning methods; (4) being capable of applying appropriate teaching concepts in classes and becoming more skilled in delivering the learning materials, so that the teaching and learning process becomes more effective; (5) being able to further develop the scope of knowledge taught to students as outlined in a standard of assessment; (6) getting a lot of input and description about the strategies and teaching methods for effective learning; (7) being able to make the learning objectives clearer, so does the learning materials and sequences, 
so that teachers become more ready and confident in teaching, and (8) developing their understanding of new and sophisticated learning media through modules obtained from self-development activities. Besides, productive teachers enrich their knowledge and skills in the field of curriculum development, vocational skills, technological development, and learning strategies and methods. However, the competency profile of productive teachers in the Building Engineering Drawing Study Program in Private Vocational High Schools has not experienced a significant increase in self-development activities and this shows their difficulties in improving their competences.

\section{References}

1. Marijan, O. (2010). Kualitas Guru Rendah, Benarkah? Artikel Pendidikan, November 4.

2. Pratama, G.N.I.P. \& Triyono, M.B. (2018). Development of Production Unit Model Based on Secondary High School Schoolpreneurship. SHS Web of Conferences, Vol. 42, p. 00110. DOI: 10.1051/shsconf/20184200110

3. Maulipaksi, D. (2015). Dana Fungsi Pendidikan dari APBN 2015 Diprioritaskan untuk Peningkatan Kualitas Guru. Jakarta, Indonesia: Indonesian Ministry of Education and Culture.

4. Wahyuni, T. (2015). Sertifikasi Guru Tak Jamin Peningkatan Mutu. CNN Indonesia.com. June 11, P. 1. Available at: https://www.cnnindonesia. com/nasional/20150611154640-20-59410/sertifikasi-guru-tak-jamin-peningkatan-mutu

5. Pratama, G.N.I.P. \& Triyono, M.B. (2015). The Implementation of CLTSMK Method to Improve Learning Quality of SMK. Jakarta: Universitas Negeri Jakarta, Indonesia.

6. Hartono, R., Mahmud, A. and Sri Utaminingsih, N. (2014). Faktor-Faktor yang Mempengaruhi Kelemahan Pengendalian Intern Pemerintah Daerah. Call of Paper in Simposium Nasional Akuntansi 17 Mataram, Lombok, Universitas Mataram.

7. Creten, S. \& Huyghe, S. (2013). Teaching at the University of Leuven; a Case of Teacher Training in Higher Education in Flanders, Belgium. Revista de Docencia Universitaria, Vol. 11, pp. 73-90.

8. Gulec-Aslan, Y. (2013). A Training Programme for a Teacher Working with a Student with ASD;
An Action Research. Educational Sciences: Theory \& Practice. Vol. 13, pp. 2229-2246.

9. Hijriyah, Al W. (2016). Pendidikan Boyolali; Pemkab Kekurangan 99 Guru Jenjang SMK. Solo Pos, April 18.

10. Arpentieva, M.R., Kassymova, G.K., Lavrinenko, S.V., Tyumaseva, Z.I., Valeeva, G.V., Kenzhaliyev, O.B., Triyono, M.B., Duvalina, O.N., Kosov, A.V. (2019). Environmental Education in the System of Global and Additional Education. Bulletin of National Academy of Sciences of the Republic of Kazakbstan. Vol. 3, (379), pp. 11-18. DOI: https://doi.org/10.32014/2019.2518-1467.45

11. Kassymova, G.K., Stepanova, G.A., Stepanova, O.P., Menshikov, P.V., Arpentieva, M.R., Merezhnikov, A.P., Kunakovskaya, L.A. (2018). Self-Development Management in Educational Globalization. International journal of education and information technologies. Vol. 12 (12), pp. 171-176.

12. Kassymova, G.K., Tokar, O.V., Tashcheva, A.I., Slepukhina, G.V., Gridneva, S.V., Bazhenova, N.G., Shpakovskaya, E.Yu., Arpentieva M.R. (2019). Impact of Stress on Creative Human Resources and Psychological Counseling in Crises. International journal of education and information technologies. Vol. 13 (1), pp. 26-32.

13. Kassymova, K.G., Tyumaseva, Z.I., Valeeva G.V., Lavrinenko, S.V, Arpentieva, M.R., Kenzhaliyev, B.K, Kosherbayeva, A.N., Kosov, A.V., Duvalina, O.N. (2019). Integrative Model of Student and Teacher Stress Coping: The Correction of Relations in Educational, Professional and Personal Interaction. Bulletin of National Academy of Sciences of the Republic of Kazakbstan. Vol. 3, (379), pp. 2-11. DOI: https://doi. org/10.32014/2019.2518-1467.53

14. Stepanova, G.A., Tashcheva, A.I., Stepanova, O.P., Menshikov, P.V., Kassymova, G.K., Arpentieva, M.R., Tokar, O.V. (2018). The Problem of Management and Implementation of Innovative Models of Network Interaction in Inclusive Education of Persons with Disabilities. International Journal of Education and Information Technologies. Vol. 12, pp. 156-162.

15. Stepanova, O.P., Gridneva, S.V., Menshikov, P.V., Kassymova, G.K., Tokar, O.V., Merezhnikov, A.P., Arpentieva, M.R. (2018). ValueMotivational Sphere and Prospects of the Deviant Behavior. International journal of education and information technologies. Vol. 12, pp. 142-148. 
16. Wardoyo, C. (2015). The Measurement of Teacher's Personality Competence and Performance Using Embedded Model. Journal of Education and Practice. Vol. 6, no. 26, pp. 18-23.

17. Depdikbud (2005). Government Regulation No. 19 of 2005 on National Standard of Education (on Teachers and Lecturers). Jakarta: Balitbang Depdiknas.
18. Depdikbud (2005). Act No. 14 of 2005 on Teachers and lecturers. Bandung: Penerbit Fokus Media. Undang-Undang Republik Indonesia. Nomor 14 Tahun 2005 tentang Guru dan Dosen. 2005. Bandung: Citra Umbara.

The paper was submitted 16.12.19. Accepted for publication 14.01.20

\section{Оптимизация деятельности профессиональных школ в повышении компетенций педагогов}

Трийоно Брури Мохамад - А-р пед., наук, проф. инженерного факультета и программы последипломного образования по технологии, зав. кафедрой технических средств обучения. Orcid ID: 0000-0001-5720-9604.E-mail: bruritriyono@uny.ac.id.

Высшая школа Ажакартского государственного университета, Ажакарта, Индонезия Azpec: Jl. Colombo No.1, Karang Malang, Caturtunggal, Kec. Depok, Kabupaten Sleman, Daerah Istimewa Yogyakarta 55281, Indonesia

Мохиб Наджуа - А-р пед. наук, доцент факультета педагогических наук. E-mail: najoua.mohib@unistra.fr.

Страсбургский университет, Страсбург, Франция

Aдpec: 4 rue Blaise Pascal, CS 90032, F-67081, 67070 Strasbourg Cedex, Strasbourg, Alsace, France Кассымова Гульжаина Куралбаевна - канд. наук (PhD), докторант. E-mail: zhaina.kassym@gmail.com

Казахский национальный педагогический университет им. Абая, Алмата, Казахстан

Адрес: 050010, Казахстан, Алматы, Проспект Аостык, 13

Высшая школа Ажакартского государственного университета

Aдpec: Jl. Colombo No.1, Karang Malang, Caturtunggal, Kec. Depok, Kabupaten Sleman, Daerah Istimewa Yogyakarta 55281, Indonesia

Пратама Галех Нур Индриатно Путра - преподаватель кафедры гражданского образования, образования и планирования, инженерный факультет. E-mail: galeh@uny.ac.id

Высшая школа Ажакартского государственного университета, Ажакарта, Индонезия

Aдpec: Jl. Colombo No. 1, Karang Malang, Caturtunggal, Kec. Depok, Kabupaten Sleman, Daerah Istimewa Yogyakarta 55281, Indonesia

Адинда Аина - канд. наук (PhD), доцент. Orcid ID:0000-0002-5879-1349.E-mail:d.adinda@unistra.fr Страсбургский университет, Страсбург, Франция

Aдpec: 4 rue Blaise Pascal, CS 90032, F-67081, 67070 Strasbourg Cedex, Strasbourg, Alsace, France Арпентьева Мариям Равильевна - А-р психол. наук, доцент, проф. кафедры психологии развития и образования. E-mail: mariam_rav@mail.ru

Калужский государственный университет им. К.Э. Циолковского, Калуга, Россия Адрес: 248023, Калужская область, г. Калуга, ул. Степана Разина, 26

Аннотация. Исследование направлено на оценку возможностей выявления и повышения компетентности и развития отдельных педагогических компетениий у преподавателей инженерных дисчиплин в средних и частных профессиональных средних школах в Слеман-Ридженси (Индонезия). Оиенка проводилась по итогам участия педагогов в программе, направленной на развитие личностной психологчческой, а также партнёрской и профессиональной 
зрелости (сочиокультурных аспектов профессиональной компетентности). Исследование бълло проведено в двух государственньх профессиональньх средних школах Индонезии и одной частной профессиональной средней школе. Оно носило качественньй характер, предполагало использование интервью и документачии в качестве средства сбора данньх. Плтнадцать наиболее успешных преподавателей трёх профессиональных средних школ, имеюших опьт в области инженерного рисования зданий (BED), были отобрань в качестве объектов исследования. Полученные даннье в виде записей интервью, фотографий и документов были сопоставлены для обеспечения достоверности полученных данньх. Затем данные бьли систематизировань и рассмотрень в ходе трёх основных этапов исследования, включая открытое кодирование, осевое кодирование и выборочное кодирование. Результать показьваюот, что благодаря направленному саморазвитию преподаватель может улучшить свои педагогические и профессиональные компетениии. Такая программа также побуждает его $к$ развитию и совершенствованию своих знаний и навьков в области основной и смежньх учебньх программ, включая технологические аспекть экспертизы, стратегий и методов обучения и т.д. Тем не менее если речь идёт о нашболее успешньх преподавателях, работаюших $b$ частных профессиональных средних школах, предложенная программа саморазвития повьшает их компетентность незначительно: они развиваются эффективно и продуктивно без дополнительных внешних стимулов. Это говорит о том, что педагогическая деятельность ориентирует спечиалиста на постоянное совериенствование сама по себе.

Ключевые слова: педагогическая компетентность, профессиональная компетентность, саморазвитие, профессиональньй вуз

Аля цитирования: Triyono, B.M., Mohib, N., Kassymova, G.K., Pratama, G.N.I.P., Adinda D., Arpentieva, M.R. The Profile Improvement of Vocational School Teachers' Competencies // Bысшее образование в России. 2020. Т. 29. № 2. С. 151-158.

DOI: https://doi.org/10.31992/0869-3617-2020-29-2-151-158

Статья поступила в редакиию 16.12.19

Принята к публикачии 14.01.20

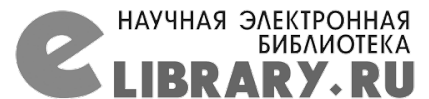

ВОПРОСЫ ОБРАЗОВАНИЯ

ПСИХОАОГИЧЕСКАЯ НАУКА И ОБРАЗОВАНИЕ

СОЦИОЛОГИЧЕСКИЕ ИССАЕАОВАНИЯ

ВЫСШЕЕ ОБРАЗОВАНИЕ В РОССИИ

ОБРАЗОВАНИЕ И НАУКА

ИНТЕГРАЦИЯ ОБРАЗОВАНИЯ

ВОПРОСЫ ФИАОСОФИИ

УНИВЕРСИТЕТСКОЕ УПРАВАЕНИЕ: ПРАКТИКА И АНААИЗ

ПЕААГОГИКА

ЭПИСТЕМОАОГИЯ И ФИАОСОФИЯ НАУКИ

ИНЖЕНЕРНОЕ ОБРАЗОВАНИЕ

ФИ ОСОФСКИЕ НАУКИ

ВЫСШЕЕ ОБРАЗОВАНИЕ СЕГОАНЯ

Alma Mater
Пятилетний импакт-фактор

РИНЦ-2018, без самоцитирования

2,255

2,040

1,709

1,124

0,945

0,905

0,858

0,751

0,653

0,540

0,397

0,319

0,276

0,257 